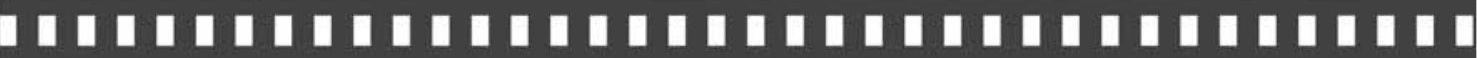 Adaptações cômicas em metáforas \\ (de humor digital) na tematização da greve dos professores do Paraná em 2015

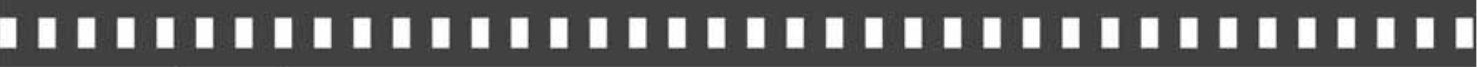

Sérgio Luiz Gadini

Isadora Ortiz de Camargo

Artigo recebido em: 22/09/2015

Artigo aprovado em: 11/12/2015 


\title{
Adaptações cômicas em metáforas (de humor digital) na tematização da greve dos professores do Paraná em 2015
}

\author{
Comic adaptations in digital metaphors in \\ thematic coverage about teachers's strike in Paraná, 2015
}

\author{
Sérgio Luiz Gadini * \\ Isadora Ortiz de Camargo **
}

\begin{abstract}
Resumo: As manifestações críticas registram experiências $e$ envolvem a utilização de uma variedade de dispositivos, meios e técnicas. A greve dos servidores públicos do Paraná, no primeiro semestre de 2015, afetou diversos setores da administração (como as universidades estaduais) durante mais de 100 dias e possibilitou $o$ uso de incontáveis recursos de expressão. O texto aborda o compartilhamento de informação pelo uso de imagens de integrantes do grupo político responsável pela administração do Paraná, que se tornaram motivos de piada viral ou 'meme', em boa medida impulsionada pelo uso das redes sociais.
\end{abstract}

Palavras-chave: Resistência (política) cultural. Humor gráfico digital. Memes. Greve dos professores no Paraná 2015. Redes sociais.

\begin{abstract}
The critics protests recording experiences and involving the use of a device's variety, medias and techniques. The strike by public Paraná servers in first half of 2015 affected several sectors of administration (such as state universities) for more than 100 days and allowed the use of countless resources of expression. This paper treats about information spread through the use of pictures of political group members responsible for Paraná's administration, which became reasons for joke, virals or 'memes', largely driven by use of social media.
\end{abstract}

Keywords: Political resistance culture. Digital graphic humor. Memes. Teachers' strike in Paraná 2015. Social media.

* Doutor em Ciências da Comunicação pela Universidade do Vale do Rio dos Sinos (UNISINOS). Professor do Departamento de Jornalismo da Universidade Estadual de Ponta Grossa (UEPG).

** Doutora em Comunicação pela Universidade de São Paulo (USP). 


\section{Considerações Introdutórias}

A ironia como estratégia de provocação pode funcionar como um gesto de irreverência e desafio à 'ordem' vigente nas estruturas sociais. Seja em forma de sátira, paródia, riso ou ironia são algumas das expressões metafóricas mais freqüentemente utilizadas por atores (individuais ou coletivos) para representar situações desagradáveis, registrar discordâncias ou ainda motivar adesões de crítica.

De um modo geral, em tais representações raramente se observa elogio ou o destaque de eventuais qualidades 'positivas' nos atores ilustrados. Daí porque se diz, historicamente, que a charge, o cartum, a tira e também demais formas de ilustração que ganham espaço na mídia são marcadas pela irreverência da crítica.

Um estudo clássico sobre A cultura popular na Idade Média e no Renascimento, de Mikhail Bakhtin (2002), recupera algumas circunstâncias e referências históricas que envolvem a presença e o uso do riso. Segundo o autor (p.5), "no folclore dos povos primitivos encontra-se, paralelamente aos cultos sérios (por sua organização e seu tom), a existência de cultos cômicos, que convertiam as divindades em objetos de burla e blasfêmia ('riso ritual'); paralelamente aos mitos sérios, mitos cômicos e injuriosos; paralelamente aos heróis, seus sósias paródicos".

O uso de recursos que envolvem humor - em fala, olhar, impresso ou digital - remetem a "formas e símbolos da linguagem carnavalesca", em geral, marcados pelo "lirismo da alternância e da renovação, da consciência da alegre relatividade das verdades e autoridades no poder" (Bakhtin, 2002, p.10).

É como se riso, no canto da boca do mais simples transeunte, ganhasse forma no imaginário popular, provocando um olhar contemplativo que, ao se identificar com o exagero ou absurdo de uma relação de poder, vê o tal poderoso por um viés 'minimalista', 
sugerindo um 'destronamento' momentâneo de autoridade política, religiosa, cultural ou econômica. É o momento em que, sem condição de destituir tal o agente (vítima da paródia), a crítica representa o leitor/ouvinte/telespectador pela identificação com a irreverência da produção cultural (midiática) em circulação.

O uso da expressão cômica (riso e afins) não é uma exclusividade dos segmentos populares, uma vez que historicamente envolve os mais diversos setores sociais. A descontração de contos, relatos ou causos populares - em rodas de conversa, feiras abertas, bares ou tabernas e praças públicas - é, pois, um hábito que reúne pessoas em encontros casuais para ouvir uma história, piada ou charada. Um pouco próximo, guardadas as proporções, do 'homem' da cobra, que segura um réptil na mão, enquanto convida os transeuntes para, em seguida, oferecer um produto de consumo. A descontração também era registrada na literatura cômica latina da Idade Média, onde se encontram produções com paródias sacras na forma de preces, sermões, canções natalinas, lendas sagradas, dentre outros formatos discursivos. Nas canções populares, por exemplo, em especial nas trovas de duplas, paródias cômicas chamam atenção das pessoas que circulam em espaços festivos ou de integração cultural.

Um outro aspecto do humor clássico apresentado por Mikhail Bakhtin é o uso do grotesco nas representações cômicas. Conforme o autor, "no realismo grotesco, a degradação do sublime não tem um caráter formal ou relativo. $\mathrm{O}$ 'alto' e o 'baixo' possuem aí um sentido absoluta e rigorosamente topográfico" (2002, p. 18). Isso porque, na Idade Média, enquanto o baixo é entendido como o mundo terreno, o alto indicaria a dimensão celestial. No aspecto corporal, "o alto é representado pelo rosto (a cabeça), e o baixo pelos órgãos genitais, o ventre e o traseiro". Pelas imagens grotescas, pintadas ou desenhadas em peças impressas (literárias ou teatrais), as representações revelam um mundo imperfeito, mundano talvez.

Em caricaturas e imagens satíricas, um pouco próximo desta 
perspectiva, governantes, líderes religiosos ou empresariais saem exagerados em traços que exacerbam marcas desproporcionais, em geral associadas a problema de caráter, desumano, autoritário, com hábitos extravagantes e desrespeitosos, dentre outras características que apelam e provocam riso, reações cômicas e, pois, modos populares de desprezo para com gestores e autoridades que se apropriam do dinheiro do contribuinte.

$\mathrm{Na}$ medida em que as condições de produção e circulação de impressos se tornam mais propícias, a arte cômica e humorística ganha força e deixa o setor literário para integrar outros setores que envolvem representação cultural e artística.

É, entretanto, com a digitalização da imagem (pós-anos 1990, se considerar a realidade brasileira), aliado à ampliação do acesso a computadores, que a produção de imagens passa, cada vez mais, a contar com 'intervenções' dos mais diversos atores e grupos sociais, ampliando as condições de uso do humor gráfico em versões adaptadas que circulam na internet e, de forma mais acentuada, em redes sociais informativas.

Um detalhe importante no compartilhamento de memes diz respeito ao crédito autoral de imagem. Na maioria das situações, e isso acontece com boa parte das imagens aqui utilizadas, não há identificação do autor, pois decorre de 'apropriações' adaptadas por diversos usuários conectados, que lançam tais montagens nas redes sociais e raramente reivindicam autoria pelas produções. Em alguns casos, a busca pela nomeação das imagens resultou em dificuldades de apontar a origem das mesmas. Daí porque este paper optou por indicar na lista de figuras utilizadas a classificação de "autoria livre", e coletiva, na medida em que se espalha nas mídias sociais pode passar por alterações e adaptações, ganhando outras versões, que também se proliferam no ambiente digital. 


\section{Humor e 'mimetização' (digital) da greve dos professores}

É a partir deste tópico que o presente texto discute a produção e circulação de 'memes' na internet, a partir da representação da greve dos professores paranaenses em 2015, por meio de 'paródias digitais'. O texto foca a 'mimetização' de personagens governistas na greve docente que durou mais de três meses acabou se tornando um recurso de crítica, que envolveu e mobilizou opiniões e manifestações de milhares de trabalhadores, simpatizantes ou mesmo pessoas que não estavam diretamente envolvidas com os movimentos reivindicatórios durante o primeiro semestre de 2015 em todo o Estado do Paraná.

A greve dos servidores públicos paranaenses iniciou dia 9 de fevereiro, quando deveria começar o ano letivo 2015. Na ocasião, o Governo do Paraná, através do chefe do executivo (Carlos Alberto Richa, PSDB), enviou projeto ao legislativo estadual, prevendo mudança no regime de previdência pública. A primeira etapa da greve, que encerrou em 12 de março para a maioria dos segmentos reinvindicatórios, resultou na retirada dos projetos e o compromisso formal do governo em rever a proposta que, a partir de diálogos com entidades sindicais, deveria enviar uma outra versão negociada da proposta. Isso tudo depois da ocupação da assembléia legislativa (ALEP) por parte dos servidores que na primeira tentativa de votação às portas fechadas, envolvendo o uso de camburão que levou deputados até a entrada do prédio da assembléia, sob o temor com os manifestantes.

No Início de abril, entretanto, o mesmo governo "esqueceu" o acordo, enviando o mesmo projeto. A segunda etapa da mesma greve, portanto, foi retomada entre 10 e 15 de abril, de modo gradativo pelos diversos setores do funcionalismo estadual. A negociação não avançou e o governo, em acordo prévio com os 
demais poderes - maioria parlamentar na ALEP, aval judicial prévio julgando ilegal qualquer manifestação pública, entre outras ações autoritárias - montou um palco de guerra para proibir as manifestações dos servidores públicos, o que resultou no "Massacre de 29 de abril", em função da abusiva estrutura policial: cerca de 4,8 mil militares (entre recrutados de todo estado, cordão de isolamento e apoio) para jogar milhares de bombas de gás lacrimogêneo, disparar balas de borracha e acionar spray de pimenta, centenas de cães treinados para agredir manifestantes, dois helicópteros para atacar os manifestantes pelo alto, dentre outras táticas que envolveram a operação de guerra planejada pelo governo para agredir os 20 mil manifestantes que estavam no Centro cívico na fatídica tarde de um "outono ditatorial".

A greve, que só foi encerrada no final de junho, foi marcada por incontáveis atividades de rua, atos, passeatas, vigílias, aulas públicas em espaço aberto, debates e reuniões em busca de soluções possíveis. E, ao longo deste período, os diversos grupos lançaram mão de representações imagéticas que ganharam força e circulação na internet - através de sites, blogs, mas principalmente em redes sociais, como twitter, facebook e whats app - e viralização. Dentre tais imagens destacam-se os memes, adaptados de situações reais, em que atores grevistas, simpatizantes ou apoiadores do movimento postaram, imprimindo um caráter cômico aos personagens retratados em tais expressões.

É este o objeto empírico do presente texto, que discute algumas adaptações cômicas em metáforas (de humor digital) na tematização da greve dos professores do Paraná em 2015. Para melhor situar o cenário de que fala, segue um breve quadro sintético com as referências pontuais que marcaram a greve dos servidores paranaenses ao longo do primeiro semestre do ano letivo (2015). 


\begin{tabular}{|l|l|}
\hline Data & Acontecimento \\
\hline $09 / 02 / 2015$ & $\begin{array}{l}\text { Início da greve dos professores da rede estadual } \\
\text { de ensino }\end{array}$ \\
\hline $04 / 03 / 2015$ & $\begin{array}{l}\text { Atendendo pedido de liminar do governo } \\
\text { estadual, o desembargador Luiz Mateus de Lima, } \\
\text { do Tribunal de Justiça do Paraná, determina o fim } \\
\text { da greve, sob pena de multa diária de R } \$ 20 \text { mil ao } \\
\text { sindicato dos educadores. }\end{array}$ \\
\hline $09 / 03 / 2015$ & $\begin{array}{l}\text { Governo estadual define propostas para os itens } \\
\text { de reivindicação, em uma "carta compromisso" } \\
\text { assinada no dia } 6 \text { de março, e professores decidem } \\
\text { em assembleia suspender a greve. }\end{array}$ \\
\hline $12 / 03 / 2015$ & \begin{tabular}{l} 
Início das aulas após o fim da greve. \\
\hline
\end{tabular} \\
\hline
\end{tabular}




\begin{tabular}{|c|c|}
\hline $27 / 04 / 2015$ & $\begin{array}{l}\text { Começa a segunda etapa da greve. Ela é retomada } \\
\text { porque, segundo o sindicato dos educadores, o } \\
\text { governo estadual descumpriu item da carta } \\
\text { compromisso, de fazer um amplo debate sobre o } \\
\text { projeto de lei que muda o fundo de previdência } \\
\text { dos servidores. Já o governo estadual defende que } \\
\text { o debate foi feito e inclui um novo projeto de lei } \\
\text { da previdência na pauta da Assembleia } \\
\text { Legislativa do Estado. Outros servidores do } \\
\text { Estado - como os professores universitários - } \\
\text { também iniciam paralisações em protesto contra a } \\
\text { votação do projeto de lei. No mesmo dia, } \\
\text { atendendo a um pedido do governo estadual, o } \\
\text { desembargador Luiz Mateus de Lima se } \\
\text { manifesta contra a retomada da greve e estabelece } \\
\text { uma multa diária de R\$ } 40 \text { mil ao sindicato dos } \\
\text { educadores caso os professores permaneçam fora } \\
\text { das salas de aula, além de uma multa diária de R\$ } \\
500 \text { ao presidente da entidade, Hermes Leão } \\
\text { Silva. }\end{array}$ \\
\hline $29 / 04 / 2015$ & $\begin{array}{l}\text { Professores são proibidos de acompanhar a sessão } \\
\text { do Legislativo que discutia o projeto de lei da } \\
\text { previdência. Do lado de fora, os policias militares } \\
\text { que cercavam o prédio da Assembleia Legislativa } \\
\text { reagem violentamente contra o protesto dos } \\
\text { professores. }\end{array}$ \\
\hline $30 / 04 / 2015$ & $\begin{array}{l}\text { O governador Beto Richa (PSDB) sanciona a lei } \\
\text { da previdência. }\end{array}$ \\
\hline
\end{tabular}




\begin{tabular}{|c|c|}
\hline $05 / 05 / 2015$ & $\begin{array}{l}\text { Servidores e população em geral realizam em } \\
\text { Curitiba um ato de repúdio ao episódio do } 29 \text { de } \\
\text { abril. Na sequência, ainda pela manhã, } \\
\text { representantes do Fórum Estadual dos Servidores } \\
\text { (FES) se reúnem com a secretária de } \\
\text { Administração e Previdência, Dinorah Nogara, } \\
\text { para tratar da data-base. Servidores querem ao } \\
\text { menos a correção inflacionária, de } 8,17 \% \text { (IPCA), } \\
\text { mas o governo estadual não garante a aplicação } \\
\text { do índice e pede mais uma semana para a pasta da } \\
\text { Fazenda estudar possibilidades. À tarde, sob } \\
\text { influência da indefinição em torno da data-base, } \\
\text { os professores decidem em assembleia manter a } \\
\text { greve. }\end{array}$ \\
\hline $06 / 05 / 2015$ & $\begin{array}{l}\text { Cai o secretário de Educação, Fernando Xavier } \\
\text { Ferreira, na esteira do episódio do último dia } 29 . \\
\text { Sua exoneração também era cobrada pelo } \\
\text { sindicato dos educadores, que alegavam não ter } \\
\text { diálogo com Ferreira. Ana Seres Trento Comin } \\
\text { assume a pasta. }\end{array}$ \\
\hline $08 / 05 / 2015$ & $\begin{array}{l}\text { Ainda na esteira do episódio do dia } 29 \text {, o coronel } \\
\text { César Kogut faz críticas a Fernando Francischini, } \\
\text { secretário de Segurança Pública, e pede } \\
\text { exoneração do comando da Polícia Militar. } \\
\text { Francischini pede demissão na sequência. }\end{array}$ \\
\hline
\end{tabular}




\begin{tabular}{|l|l|}
\hline $12 / 05 / 2015$ & $\begin{array}{l}\text { Em nova reunião sobre a data-base, governo } \\
\text { estadual mantém indefinição sobre data-base e } \\
\text { pede mais uma semana ao FES. Servidores saem } \\
\text { indignados da reunião e reforçam discurso em } \\
\text { defesa da greve. Governo estadual repete que a } \\
\text { greve foi retomada sem motivo, já que entende } \\
\text { que as discussões sobre a previdência foram } \\
\text { realizadas, e critica a "mudança de pauta" da } \\
\text { categoria, em referência à data-base. }\end{array}$ \\
\hline $14 / 05 / 2015$ & $\begin{array}{l}\text { O governo do Paraná anuncia o fim das } \\
\text { negociações com os servidores e o envio de um } \\
\text { projeto de lei ao Legislativo prevendo um índice } \\
\text { de reajuste de 5\%. O pagamento seria feito em } \\
\text { duas parcelas, sem definição de datas. }\end{array}$ \\
\hline $19 / 05 / 2015$ & $\begin{array}{l}\text { FES cobra a retomada do diálogo e o governo } \\
\text { estadual marca uma nova reunião com os } \\
\text { representantes dos servidores, no Palácio Iguaçu. } \\
\text { Na reunião, contudo, é mantida a disposição do } \\
\text { Executivo de levar o índice de 5\% para análise do } \\
\text { Legislativo. A reunião ocorre em meio a um } \\
\text { protesto no Centro Cívico, organizado pelo FES. }\end{array}$ \\
\hline $\begin{array}{l}\text { Pressionada por servidores, a base aliada na } \\
\text { oficialmente que só aceita votar o reajuste do } \\
\text { funcionalismo se ele for de } 8,17 \% .\end{array}$ \\
\hline $15 / 05 / 2015$
\end{tabular}




\section{7/05/2015 Com base em duas propostas levadas pelos parlamentares, governo estadual propõe outro projeto de lei. O Executivo oferece um reajuste de $3,45 \%$ parcelado em três vezes, nos meses de setembro, outubro e novembro. Este índice foi calculado com base na inflação do período entre maio e dezembro de 2014. O texto também prevê a antecipação da data-base do funcionalismo, de 1. ${ }^{\circ}$ de maio para $1 .^{\circ}$ de janeiro. Assim, no início de 2016, o governo estadual se compromete a fazer a revisão dos salários com base no IPCA entre janeiro e dezembro de 2015. A nova proposta, contudo, não agrada aos servidores, que resolvem não convocar assembleias para deliberar sobre o assunto. \\ Defensoria Pública do Paraná entra com uma ação civil pública contra o governo estadual devido ao episódio do dia 29 de abril. É pedida uma indenização de $\mathrm{R} \$ 5$ milhões por danos morais coletivos.}




\begin{tabular}{|c|c|}
\hline $28 / 05 / 2015$ & $\begin{array}{l}\text { Governo estadual pede bloqueio de R } \$ 1,24 \\
\text { milhão da APP-Sindicato, para garantir o } \\
\text { pagamento da multa definida pelo Tribunal de } \\
\text { Justiça do Paraná no último dia } 27 \text {, referente aos } \\
\text { dias parados. O governo estadual também tenta, } \\
\text { na mesma petição, impedir o repasse, à } \\
\text { APP-Sindicato, dos valores descontados } \\
\text { mensalmente dos professores filiados à entidade. } \\
\text { O governo estadual também instala em seu } \\
\text { "Portal da Transparência" na internet um link } \\
\text { específico para divulgar os salários dos } \\
\text { professores. Docentes reclamam de "valores } \\
\text { distorcidos". }\end{array}$ \\
\hline $01 / 06 / 2015$ & $\begin{array}{l}\text { Deputados estaduais fazem nova proposta de } \\
\text { reajuste ao Executivo. A proposta prevê a } \\
\text { aplicação de } 3,45 \% \text { em outubro e de } 4,56 \% \text { em } \\
\text { dezembro. Com isso, a data-base do } \\
\text { funcionalismo seria mantida em maio. Beto Richa } \\
\text { descarta o reajuste proposto por parlamentares e } \\
\text { agrava crise entre aliados. }\end{array}$ \\
\hline $02 / 06 / 2015$ & $\begin{array}{l}\text { A } 5^{\text {a }} \text { Câmara Cível do Tribunal de Justiça do } \\
\text { Paraná nega recurso à APP-Sindicato e mantém a } \\
\text { decisão liminar que determina o fim da greve. }\end{array}$ \\
\hline
\end{tabular}

1 A síntese cronológica da greve dos servidores parananenses em 2015, de autoria da Gazeta do Povo, está disponível no site do jornal:

http://www.gazetadopovo.com.br/vida-e-cidadania/cronologia-bxyes24fyo4r7knblzc9uzrut 


\begin{tabular}{|c|c|}
\hline $03 / 06 / 2015$ & $\begin{array}{l}\text { Surge uma nova proposta de reajuste, afinada } \\
\text { entre governo estadual e parlamentares. A ideia } \\
\text { agora é pagar } 3,45 \% \text { (referente à inflação de maio } \\
\text { a dezembro de } 2014 \text { ) em uma única parcela, em } \\
\text { outubro deste ano. A inflação de } 2015 \text { seria } \\
\text { zerada em janeiro de } 2016 \text {. As perdas } \\
\text { inflacionárias de } 2016 \text { seriam pagas em janeiro de } \\
2017 \text { - quando os servidores também ganhariam } \\
\text { um adicional de } 1 \% \text {. Além disso, a proposta prevê } \\
\text { a reposição da inflação de janeiro a abril de } 2017 \\
\text { em } 1^{\circ} \text { de maio daquele ano - quando a data-base } \\
\text { do funcionalismo estadual voltaria a ser em maio } \\
\text { e não mais em janeiro. A APP-Sindicato entende } \\
\text { que esta proposta pode ser levada para uma } \\
\text { assembleia da categoria. A deliberação sobre o } \\
\text { fim ou não da greve fica marcada para terça-feira } \\
\text { (9), às } 8 \text { horas, no estádio da Vila Capanema, em } \\
\text { Curitiba. }\end{array}$ \\
\hline $09 / 06 / 2015$ & $\begin{array}{l}\text { Mais de } 10 \text { mil professores reunidos em } \\
\text { assembleia na Vila Capanema, em Curitiba, } \\
\text { decidem pelo fim da greve. Dos } 29 \text { núcleos } \\
\text { regionais, } 23 \text { decidiram por encerrar a } \\
\text { paralisação, apesar de a proposta de reajuste } \\
\text { salarial do governo estadual protocolada na } \\
\text { Assembleia Legislativa não ter agradado a } \\
\text { categoria. }\end{array}$ \\
\hline
\end{tabular}

Fonte: Gazeta do Povo, 08/06/2015 
É no espaço das redes virtuais que este artigo destaca algumas metáforas dialógicas que narram a greve dos professores do Paraná de maneira diferente, utilizando imagens e legendas discursivas que exploram aspectos cômicos, pitorescos, entre ironia, drama e humor em situações e dificuldades enfrentadas pelos servidores públicos diante das decisões do governo estadual comandados por Beto Richa (PSDB, Demos e outros aliados).

Os referidos 'memes' digitais serviram, assim, como uma espécie de escape informacional dos discursos de imprensa oficial, ou 'alternativa' digital, aparecendo principalmente em diversas redes sociais, como Facebook, Whatsapp, Twitter e Instagram. Os memes da greve destacam situações que foram referências pontuais do movimento através de figuras de linguagem e discursos irônicos, característica comum dos memes temáticos, que aparecem como tendências que registram possibilidade de viralizar nas redes sociais e demais espaços da internet.

\section{Expressões discursivas (digitais) em memes}

O termo "meme" tem uma indicação etimológica da biologia e genética: cunhado em 1976 por Richard Dawkins no bestseller "Gene Egoísta", a expressão remete a uma unidade mínima do discurso, assim como é o gene. Daí a relação na terminologia deste recurso, que ganhou impulso ao se tornar 'ferramenta' viral nas redes sociais. A terminologia é de origem grega e significa "mimema" ou imitação (mimetismo) e, pelo inglês, foi traduzido usualmente para meme, que também remete termos 'gene' e 'memória', conforme aparecem nos textos de Dawkins.

A expressão também pode ser associada aos processos discursivos de tornar a fala em linguagem escrita ou imagética que se espalham com velocidade e facilidade como vírus. E, por sua vez, a 
biologia indica uma analogia, que associa à replicação (compartilhamento e reprodução) informacional ou a viralização dos memes, assim como se, supõe, espalham as doenças virais.

Em certos aspectos, o meme remete à memória, como replicação, da menor unidade informacional que, ao dispensar explicações detalhadas, registra facilidade em se multiplicar, na medida em que pode ser facilmente compreensível, pela própria lógica de síntese temática que carrega em si.

As redes sociais que mais registraram imagens de meme no período da greve foram Facebook, Twitter, Instagram e WhatsApp e, pois, boa parte das referidas imagens analisadas no presente estudo circularam em uma ou mais redes, operando ao mesmo tempo como expressão alternativa, na medida em que não foram previamente 'controladas' pelos tradicionais grupos de mídia. É, contudo, o Facebook, pela própria força e pluralidade de integrantes ou usuários, a rede que mais compartilhou tais memes.

Os memes traduzem e veiculam ideias, críticas, reivindicações, desejos, valores ou mesmo piadas, que são produzidas e replicadas de maneira autônoma e, na maioria das vezes, sem a identificação autoral, o que também facilita a difusão rápida das mensagens.

Oportuno considerar que, no processo de 'transferência de informação', os memes podem ser localizados teoricamente nos estudos da teoria memética, que indicam como ocorre o processo evolutivo da passagem de unidades mínimas de conteúdo de cérebro a cérebro e, pois, envolvendo vários atores. A orientação conceitual, aqui, reconhece a terminologia biológica como tradutora da funcionalidade que os memes têm e, por diferentes aspectos e dimensões, adquirem ao circular nas redes sociais.

Como a maioria das pessoas não repassa uma informação ao mero acaso, considera-se, ainda, que o uso dos memes também está associado à linguagem como repetição, que envolve comportamentos, escolhas e expressões identitárias de grupos 
sociais. Para Susan Blackmore (1999), os memes surgem no processo da expressão humana que inclui a imitação como uma das primeiras ações comunicativas.

Uma imagem (como informação) reproduzida ou parcialmente adaptada para expressar uma situação ou fato social registra a possibilidade de ser mais facilmente compreendida e, portanto, passa a circular com mais facilidade por variados atores e grupos.

Destaca-se, assim, entre as diversas características do meme na ambiência digital, a capacidade de relacionar a imagem a palavras, olhares e demais recursos, como o traço ou a inclusão de uma onomatopéia, legenda ou complemento que, diante da crescente facilidade de edição digital, tende a ser mais facilmente produzida por incontáveis atores. Em tais situações, o uso de recursos cômicos tende a contribuir para criticar ou provocar riso pela forma como as personagens são representadas.

Na medida em que os computadores e, cada vez mais, também celulares e demais dispositivos móveis trazem a possibilidade de pegar imagens e adaptar falas ou elementos afins que provocam riso ou deboche, os memes se tornam mais corriqueiros, tais como piadas, provérbios, músicas, jingles, filmes, recortes de peças publicitárias ou trocadilhos. No que diz respeito aos setores mais frequentemente ilustrados nos memes, no Brasil, pode-se dizer que a religião, política, cultura, educação, além das mais diversas ações de governo que são questionáveis publicamente se tornam alvo nas redes informacionais.

Por representar figuras de linguagem de uma evolução cultural (BLACKMORE, 1999), os memes operam como metáforas no campo digital, veiculando recados que carregam situações factuais reinterpretadas em termos semânticos. Mas isso também não é exclusividade de espaços alternativos, pois podem ser usados por corporações empresariais, mídia comercial tradicional, em formatos que envolvem produções jornalísticas, estratégias publicitárias, representações cinematográficas e afins. 
Pela força de síntese factual, que relaciona a situações com significados ambíguos, o meme digital pode ser relacionado ao papel desempenhado pela charge ou cartum com um diferencial: a facilidade com que pode circular impacta na possibilidade de viralizar, ampliando o alcance em tempos de redes sociais.

É possível, ainda, relacionar o processo de produção/circulação do meme à perspectiva da Análise Crítica do Discurso (ACD), em seus aspectos conceituais, considerando que a funcionalidade da expressão implica em modo de dizer (linguagem), aqui entendida como prática social e ideológica, que opera como interação nas ambiências digitais pelos usuários conectados, operando como prática interativa online (SOUZA, 2013).

Um levantamento preliminar indicou a produção de milhares de memes durante o período da greve dos servidores públicos paranaenses em 2015, envolvendo as diversas redes sociais. Alguns destes registravam mais adesão e compartilhamento. A escolha da amostra ao presente artigo considerou este indicador (mais freqüência e circulação), além de uma pluralidade nos recortes, envolvendo produtos variados como ponto de partida (filme, foto de jornal, cena televisiva, gesto autoritário por parte do governo, metáfora ou analogia com situações outras).

Dentre as variadas formas de expressão, que dialogam com a realidade de modo sintético, a análise aqui realizada considera ainda a eficácia comunicativa viabilizada pela síntese informativa que os memes selecionados veiculam.

$\mathrm{Na}$ maioria dos casos, trata-se uma maneira de conversação com a realidade, ora expondo dimensões que envolvem o esdrúxulo ou aspecto ridículo de uma ação humana (ainda que na função governista), lançando mão da ironia para criticar personagens em voga na sociedade, como o que aconteceu por milhares de vezes com o nome e a imagem do governador do Paraná, Carlos Alberto Richa (PSDB) durante a greve de 2015. Por incontáveis justificativas, Richa se torna o alvo de adaptações imagéticas que traduzem gestos 
e decisões autoritárias e arrogantes, provocando tais reações em leitores, internautas, ex-eleitores e contribuintes que, diante do contexto, passam a questionar o modo de governar do grupo responsável pela gestão do Estado por ocasião da greve dos servidores públicos.

Pode-se destacar que no processo de formações discursivas que rodam pelo ciberespaço há uma 'conjunção' contextual de momentos grupais e transferência de reivindicações através dos memes, que garantem espaço para expressões (informativas ou opinativas) de diferentes identidades e grupos sociais que, ao ressignificar tais práticas comunicacionais, asseguram uma codificação de situações de um mundo em plataformas de sociabilidade online (AMARAL, 2011).

Nas próximas páginas apresentamos alguns dos memes que mais circularam - registraram compartilhamentos, comentários e curtidas - no Facebook, abordando a greve dos servidores públicos paranaenses em 2015, tendo por base as principais figuras responsáveis pela gestão do Estado e, pois, diretamente envolvidos nas decisões que afetaram a vida dos grevistas. $\mathrm{O}$ que os referidos memes têm em comum dizem respeito ao uso da ironia em uma perspectiva crítica ao grupo governista no Palácio do Iguaçu (sediado em Curitiba), com destaque para a ação da polícia na agressão aos manifestantes. Algumas imagens fazem analogia a personagens de filmes, desenhos, histórias em quadrinhos ou piadas adaptadas que facilitam a 'comunicação crítica'.

Para além de pautar o contexto de que se fala, a orientação metodológica da presente análise considera a expressão da peça (meme) em sua leveza (e fluidez, na maioria das vezes, marcada pela comicidade referencial) ao tratar de um assunto angustiante e tenso, que afetou diretamente a vida de cerca de 150 mil servidores públicos e, indiretamente, também impactou na vida de mais 1,1 milhão de pessoas, se considerar o número de estudantes matriculados nas escolas públicas e nas universidades estaduais do 
Paraná no período.

A análise do produto cultural, portanto, toma por base a 'unidade' conceitual e temática do meme como expressão sígnica midiática (GADINI, 2009). E, na mesma persepectiva, a presente análise dialoga com a abordagem folkcomunicacional das manifestações culturais no campo midiático nas sociedades complexas do mundo contemporâneo (GADINI e CAMARGO, 2011).

Em alguns dos casos, as imagens originais trazem uma estética grosseira e mal acabada, própria da caracterização feita e incorporada pelos usuários das redes sociais no processo de evolução do ciberespaço e do que é aqui discutido como meme digital (figura 1).

Figura 1: Memes da greve
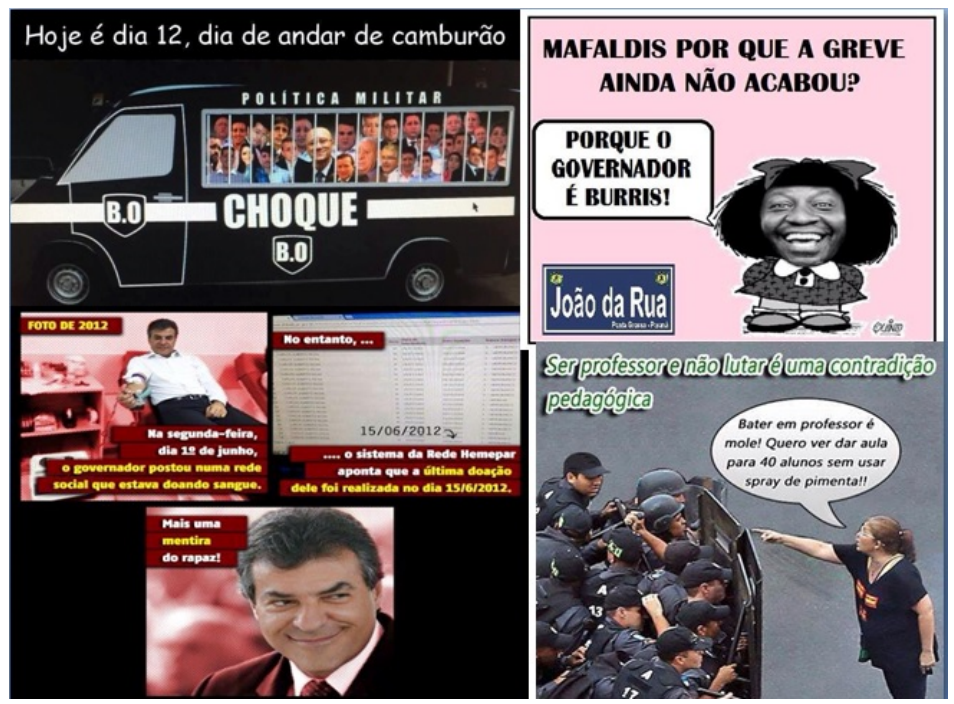

Fonte: 'Autoria livre’

$\mathrm{Na}$ imagem do quadrante superior, à esquerda, a referência ao 12 é porque foi no dia 12 de fevereiro que os deputados, por 
orientação do então secretário de Segurança (delegado Fernando Francisquini, PROS), tentaram entrar no prédio da Assembleia Legislativa de camburão com medo dos manifestantes. Foi, na linguagem popular, uma espécie de "piada pronta". Não por acaso, mais de sete meses depois da cena, a referência aos deputados que andaram de camburão continua presente no imaginário popular em diversos setores sociais. A imagem ao lado, quadrante superior direito, adapta os vícios de fala conhecidos de Mussum, um dos personagens cômicos de 'Os Trapalhões', que marcaram época da TV brasileira entre os anos 1970/80. Na imagem inferior, quadrante esquerdo, o governador Beto Richa é flagrado em contradição (mentira), pois a assessoria divulga que ele doou sangue, mas o registro da última doação confirmada pelo Hemepar é de 2012. E, ao lado, um dos flagrantes em que uma professora reclama com o policiamento armado em exagero, mas ainda temeroso.

\section{Análise de alguns memes digitais}

$\mathrm{Na}$ sequencia, apresentamos, de forma descritiva e analítica, alguns memes espalhados durante a greve e que revelam características em comum, envolvendo imagens impactantes, discursos de crítica e ironia ao governador, bem como analogias com piadas em adaptação digital. Na maioria dos casos, como se pode constatar no levantamento em redes sociais, tais imagens são impulsionadas pelo humor e adaptação cômica. Entre os memes que viralizaram vários exploram a imagem (face) do governador Beto Richa, alguns ironizam datas comemorativas, outros lembram filmes, em analogias a figuras de governos ditatoriais, como o alemão nazista Adolf Hitler (figura 3).

Nesta categoria de memes virais é possível identificar a expressão de sentimentos de raiva, decepção e usuários incrédulos diante da postura do governo frente às reivindicações dos professores estaduais. Presente na ironia, a imagem do governador é 
altiva e com sorriso discreto, o que sugere um ar de arrogância e reforça a posição crítica defendida pelos servidores públicos. No meme "Parabéns a todas as mulheres pelo Dia Internacional da Mulher... menos para as professoras" (figura 2) o discurso indica a contrariedade com a situação vigente e coloca "as professoras" na fala do governador em uma condição de exclusão, inclusive, ao direito de receber parabéns pelo dia da mulher ( 8 de março). $\mathrm{O}$ meme foi veiculado (viralizou) já na véspera do dia da mulher.

Figura 2: Meme Dia das Mulheres

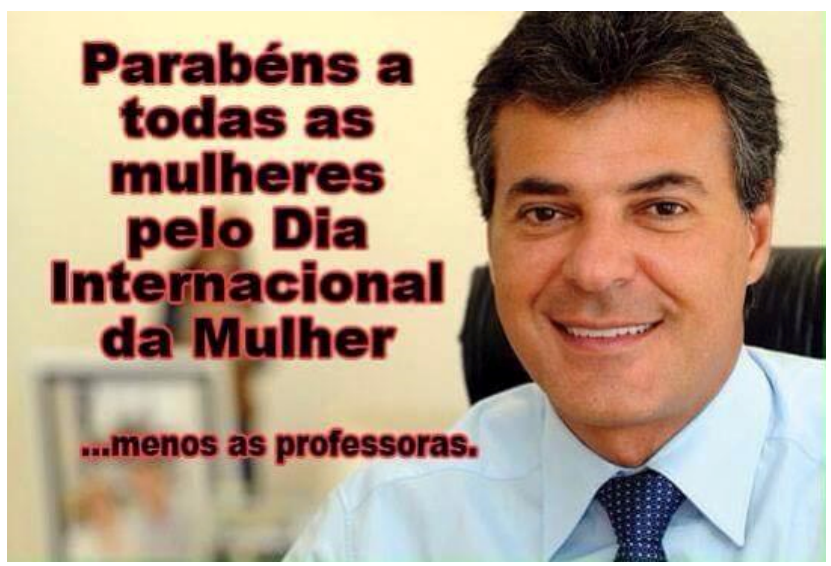

Fonte: 'Autoria livre' 
Figura 3: Meme em formato de cartaz de filme

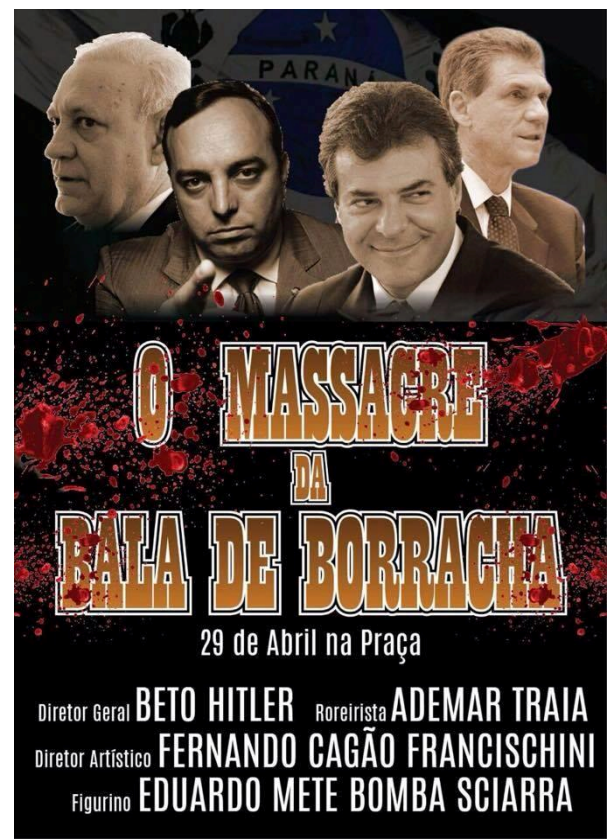

Fonte: 'Autoria livre'

A imagem da figura 3, que referencia um cartaz de filme, circulou logo após o 29 de abril, e divulga uma 'batalha' entre civis (professores e apoiadores do movimento) e a polícia militar, envolvendo o exagerado uso de bombas, balas de borracha, helicópteros e cães treinados para agredir manifestantes, proibindo-os de entrar na Assembleia Legislativa (ALEP). Destaca-se, no cartaz adaptado, as personagens responsáveis pelo "massacre" como produtores e diretores da suposta produção fílmica. Outro meme que utiliza imagem de cinema faz uma paródia ao filme Sexto Sentido (1999), parafraseando um dos diálogos mais conhecidos da peça cinematográfica ao contexto de corrupção no governo do Paraná, em que o personagem diz que "vê gente corrupta no governo Richa a todo o tempo" (figura 4). 


\section{Figura 4: Meme Sexto Sentido}

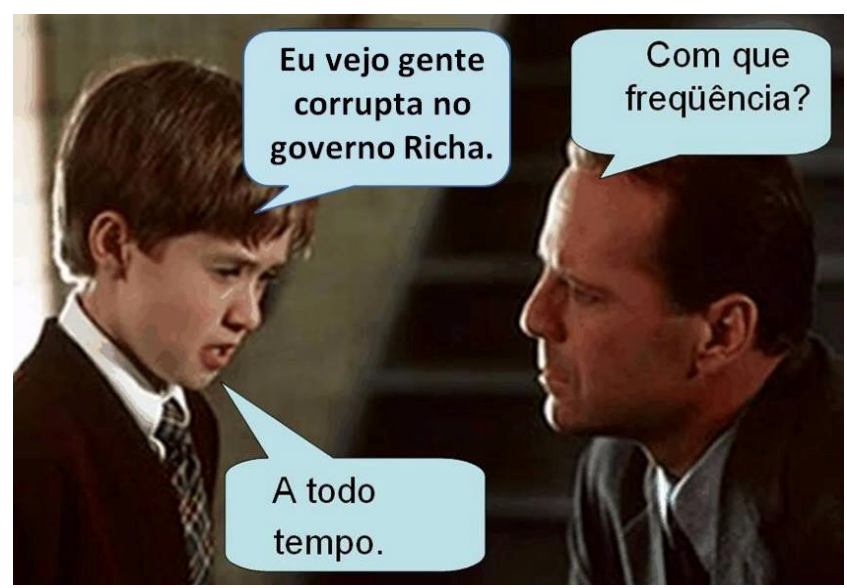

Fonte: 'Autoria livre'

Além dos memes relacionados a filmes e personagens de cinema, o período do movimento grevista registrou a viralização de piadas e analogias fálicas (como sugere a figura 5), em que o governador é apresentado como aproveitador do poder e do dinheiro público, indicando nomeados políticos como sugadores de "tetas", em uma clara relação ao termo popular "mamar na teta da vaca",onde a vítima é o dinheiro do contribuinte, que deveria ser mantido pelo Estado. Marcada por ironia, a referida imagem infantiliza o governador Richa e associa "ratos" a supostos parceiros políticos do chefe do executivo, cada um deles representando uma situação informada no período da greve, tais como "amigos assessores pedófilos"; "auxílio moradia para juízes"; "salário de esposas em cargos inúteis", dentre outras indicações. 
Figura 5: Mema Haja Teta

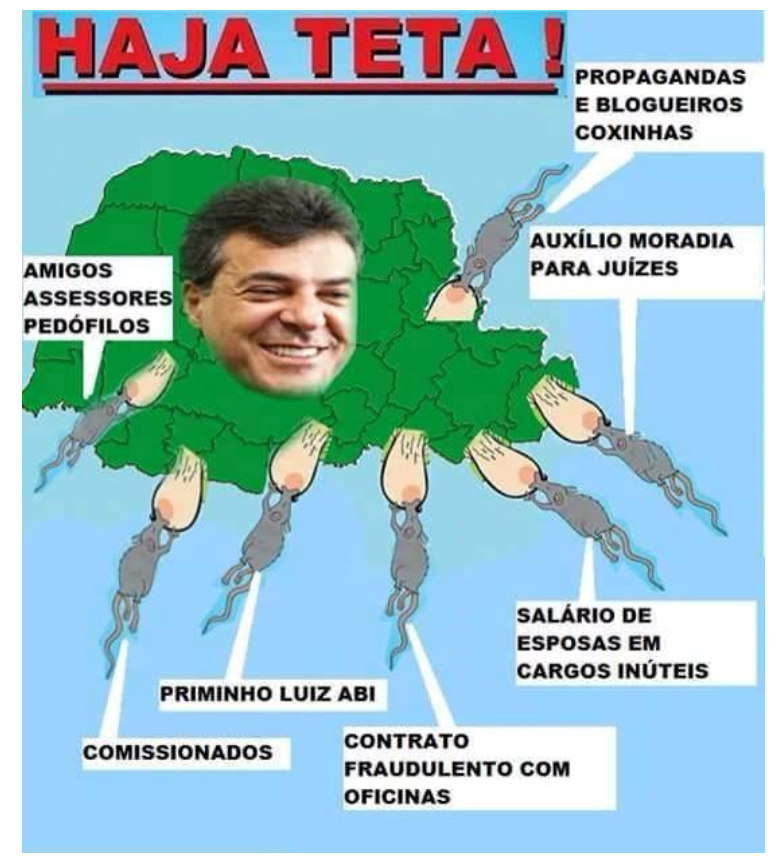

Fonte: 'Autoria livre'

A liguagem e os cópidos mais presentes nos memes veiculados durante a greve dos professores em confronto com o governo do PSDB focam modos e táticas de atores manifestantes, bem como apoiadores e simpatizantes do movimento, que postam tais imagens nas redes sociais, reforçando a crítica pública ao grupo governista teoricamente responsável pelagestão do Paraná em 2015. A ausência de identificação autoral, outra marca com nos memes digitais, também facilita tais expressões reivindicatórias no ciberespaço.

Das centenas de imagens que referenciam o governador Richa, a presente amostra fez um primeiro recorte de 50 memes e, seguida, para viabilizar a análise, escolheu alguns aqui apresentados, que ilustram e associam situações em que o chefe do executivo estadual veicula como 'ações de governo', nas páginas oficiais, 
durante a greve, como ocorreu na postagem da fanpage de Richa, que faz uma chamada para doação de sangue em 1 de junho de 2015. Nesse caso, o autor do meme pesquisa, e divulga, uma imagem de 2012, e explica (na legenda), com uma planilha, informando que a última doação de sangue do próprio governador ocorreu em 15/06/2012. O meme funciona, aqui, como a exposição de uma inverdade veiculada pela assessoria, usando da ironia para viralizar a informação (figura 6).

Figura 6: Meme Doação de Sangue

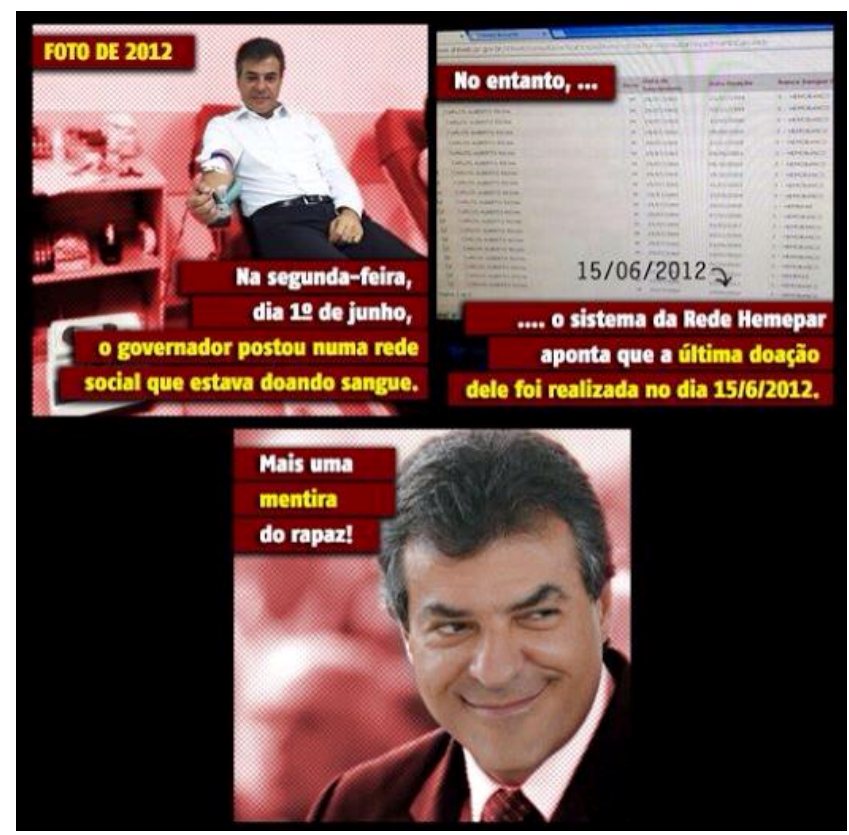

Fonte: 'Autoria livre’

$\mathrm{Na}$ figura 7, a imagem d governador é associada ao personagem Robin Hood, que, pela lenda medieval, roubava dos ricos para dar aos pobres. No meme, o governador é chamado de "Robin Hood às avessas por roubar dos pobres para dar aos ricos", 
retratando uma crítica direta feita pelos professores, pois o pagamento de férias (de 2014/15) dos servidores públicos não aconteceu, mas o executivo sancionou a lei que garante auxílio-moradia para juízes no valor de $\mathrm{R} \$ 4,4$ mil mensais. $\mathrm{Na}$ sequencia, a figura 8 traz uma versão em que o governador é asociado o Pinóquio, que aumentaria o nariz a cada mentira contada ou, neste caso, veiculada pela mídia (hegemônica e governista).

Figura 7: Meme Beto Richa Robin Hood

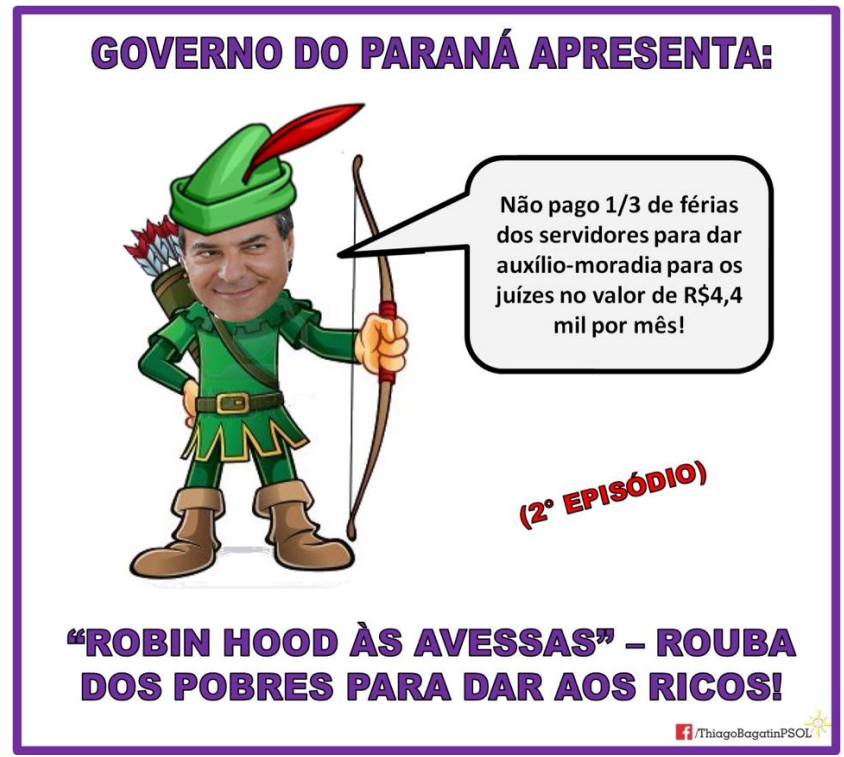

Fonte: 'Autoria livre' 
Figura 8: Beto Richa Pinóquio

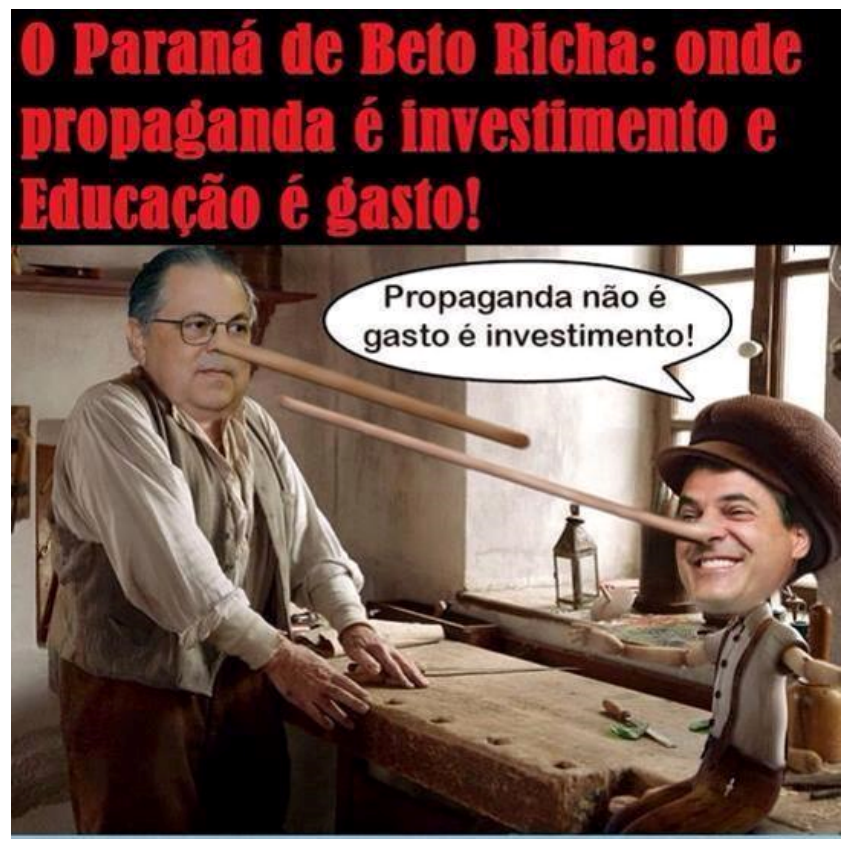

Fonte: 'Autoria livre'

Uma das falas dos manifestantes que ganhou adesão pública durante a greve foi a defesa do impeachment do governador, apresentada por diversos atores e movimentos organizados. $\mathrm{Na}$ figura 9 uma das imagens que relaciona o massacre de 29 de abril e outros desmandos governistas com a hashtag \#ForaBetoRicha, que também viralizou nas redes sociais. E, na figura 10, na mesma perspectiva, a imagem do governador é marcada pelo sangue, escorrendo na mão, em referência às agressões, que sangraram o rosto de mais de 300 servidores públicos durante a repressão militar na praça central de Curitiba em 29/04/2015. 
Figura 9: Meme Impeachment Beto Richa

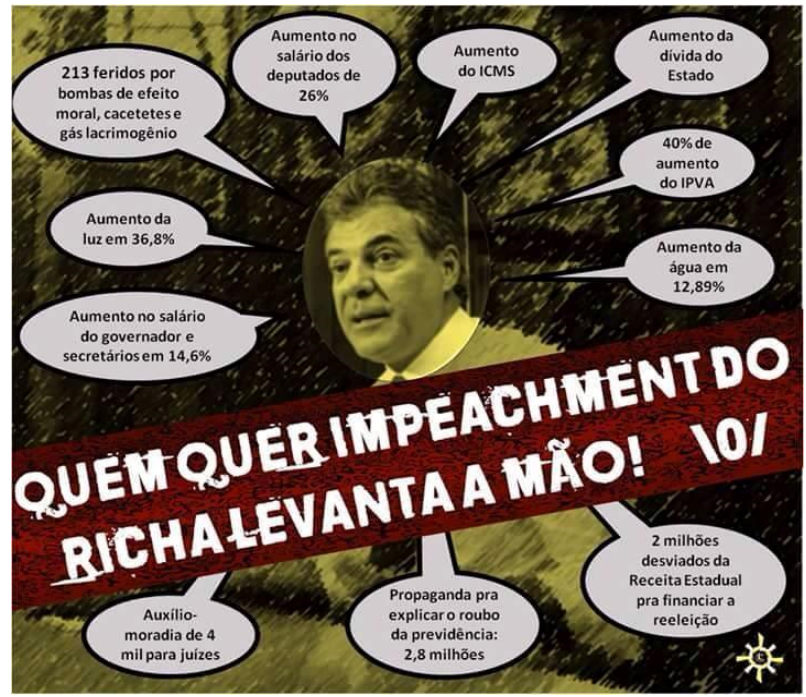

Fonte: 'Autoria livre'

Figura 10: Meme \#ForaBetoRicha

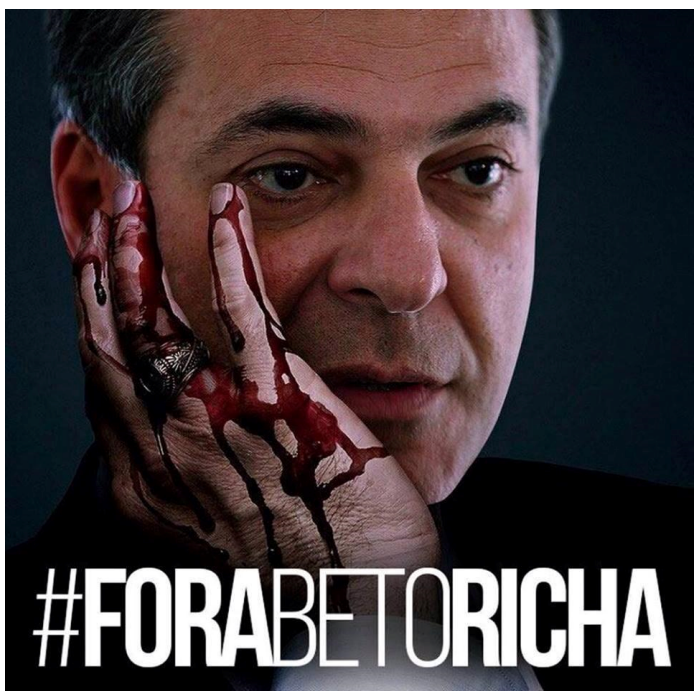

Fonte: 'Autoria livre' 
A ironia e comicidade marca a maioria dos memes que viralizaram durante a greve dos professores paranaenses em 2015. $\mathrm{Na}$ imagem 11, a irreverência recupera uma fotografia em que o governador, a esposa e o secretário de Estado Ratinho Jr (PSC) seriam "ungidos" por um pastor neo-pentecostal. A legenda, no entanto, dá o tom da crítica: o tal ato de exorcismo ou benção é indicado por um desejo coletivo: "dinheiro do Estado saia desse corpo que não é seu".

Figura 11: Beto Richa Exorcizado

\section{DINHEIRO DO ESTADO, SAIA DESSE CORPO QUE NÃOÉ SEU!}

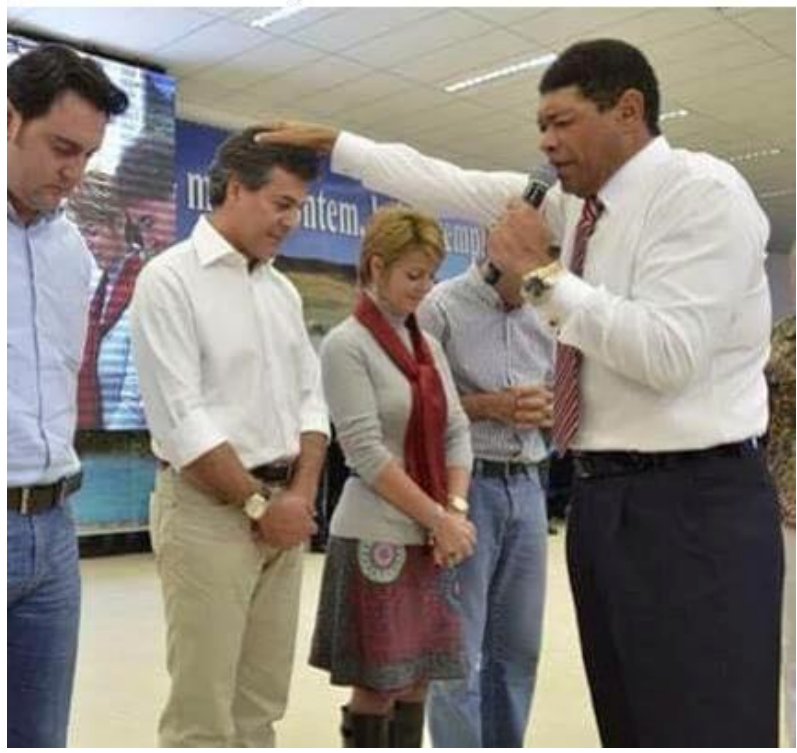

Fonte: 'Autoria livre' 


\section{Conclusões}

Em tempos de crescente uso da internet e onde as redes sociais, na maioria das vezes, não dispõem de mecanismos de controle ou censura prévia, as representações humorísticas em forma de meme funcionam como estratégias de ressignificação de fatos sociais, que registram um apelo pela possibilidade fácil compartilhamento por meio das redes digitais. E, uma vez que os memes tematizam situações amplamente questionáveis da vida social, aliado à agilidade de atores para adaptar tais casos, a viralização registra uma força de circulação que contribui para com a adesão de crítica ou aceitação por parte de uma grande parcela de pessoas que, por tais imagens, passam a ter acesso aos acontecimentos.

Em outros termos, pode-se dizer que tais expressões também operam como 'ferramentas linguísticas' em versão digital ou também atuam como formas discursivas que revelam situações publicamente inaceitáveis (pela maioria das pessoas) na realidade social, seja pelo exagero do autoritarismo, cena de desrespeito humano, apelo ou força de uma reivindicação ou mesmo pelo abuso de poder de uma determinada situação. Em tais casos, um gesto governista ganha projeção e viraliza por ganhar uma forma de piada, riso ou marca cômica humorística.

É claro que a facilitação de adaptação técnica (com recursos editoriais e de formatação), disponíveis na internet, a apropriação e criação de memes se torna, em especial para governos autoritários que não aceitam críticas e nem mesmo oposição política, uma arma para a crítica, que passa a circular com força de uma versão contestatória de desrespeito ou afronta aos direitos humanos e à condição de cidadania. Assim, freqüente nas sociedades complexas do mundo contemporâneo, nos meios e ambientes de cibercultura, os memes se tornam alternativas de expressão de grupos sociais excluídos ou tratados com desrespeito por governos.

Daí porque membros de governos autoritários tendem a ser 
mais frequentemente tematizados e alvo de produtores de memes e demais formatos de humor gráfico digital. Não há, contudo, uma única ou hegemônica variação de meme, pois depende da criatividade e ousadia dos próprios autores. E, pois, tais expressões dialogam ou se utilizam de figuras de linguagem, metáforas, paródias ou analogias variadas, que sintetizam situações em imagem, diálogo ou pensamento por meio de caricaturas, adaptações ou palavras que revelam perfis moral ou politicamente questionáveis de seus respectivos atores.

De um modo geral, pode se dizer que, por se tratar de uma forma contemporânea e alternativa de expressão, o meme também circula mais rapidamente em função da ausência de censura prévia de informação (e edição). Daí porque os autores de tais memes, na maioria das vezes, atuam por conta própria e autônoma, sem qualquer vínculo com redes ou grupos empresariais de mídia - que, por sua vez, considerando a história do Brasil, mantêm vínculos com incontáveis agentes políticos, religiosos ou econômicos, que não aceitam toda e qualquer manifestação crítica!

É nesta perspectiva que, em situações de crise ou de avanço hegemônico de grupos governistas, os memes se tornam a 'própria' mídia, na medida em que circulam de modo autônomo e tendem a viralizar (circulando rapidamente) com maior força e probabilidade de acesso e adesão. Guardadas as proporções, algumas das imagens dos memes selecionadas para este texto operaram com uma reconhecida força de viralização informativa e, pois, serviram como base de apoio à manifestação ao movimento grevista dos professores do Paraná, entre fevereiro e junho de 2015.

As imagens (memes) aqui selecionadas fazem analogias e paródias a uma série variadas de situações, tendo por base integrantes do governo do Paraná (Carlos Alberto Richa, governador, secretários de Estado, deputados que articularam a aprovação de projetos contra os docentes, dentre outros atores). $\mathrm{Na}$ amostra destacam-se referências analógicas a personagens infantis, 
histórias em quadrinhos, produções cinematográficas, refletindo um descontentamento público com as ações governistas que impactaram na vida dos servidores públicos. O caso mais tematizado fica por conta do massacre de 29 de abril, quando mais de 4 mil policiais militares dispararam milhares de bombas de gás (lacrimogêneo e pimenta), balas de borracha, além de cassetetes, dois helicópteros e centenas de cães para agredir os manifestantes no Centro Cívico curitibano. Isso tudo para proibir que os manifestantes entrassem na Assembléia Legislativa, quando foi aprovado o projeto de desmonte do ParanáPrevidência, autorizando o governo a usar recursos da contribuição dos servidores públicos Tão logo as imagens das agressões foram divulgadas, já era possível encontrar na internet, com mais ênfase nas redes sociais, imagens adaptadas com referência ao uso exagerado da força policial para agredir professores do Estado.

Os exemplos de produtos (em forma de meme digital) sobre a greve dos professores do Paraná em 2015 são, aqui, apenas situações ilustrativas que envolvem o uso do humor e da ironia como recursos de irreverência - por parte de atores, participantes diretos ou apenas colaboradores ou apoiadores eventuais do movimento reivindicatório - que operam como crítica às ações de membros do Governo do Estado, focando ora em decisões, manifestações públicas ou propostas apresentadas durante o conflito.

Em sintonia com a perspectiva histórica de Bakhtin (2002), o uso de memes como metáfora cômica funciona ainda como um mecanismo de informação crítica ao modo com que o Governo tratou e agiu durante os principais momentos que marcaram os mais de três meses da greve dos professores paranaenses. O humor gráfico digital, neste caso dos memes, se considerar a média de acessos (visualizações, curtidas, compartilhamentos e comentários), desempenhou um papel que contribuiu na divulgação, fortalecimento e divulgação do movimento grevista. E, nesse contexto, a criatividade dos atores e autores na produção de memes 
ganha destaque, pois mantinha os principais integrantes do Governo do Paraná no cenário de alvo da crítica social ao longo do período dos conflitos que marcaram a greve docente em todo o Estado durante o primeiro semestre de 2015.

$\mathrm{E}$, por fim, em tempos em que governos usam recursos públicos para custear divulgação de versões favoráveis às ações e planos de gestão, os incontáveis memes digitais que circularam na internet sobre a greve dos professores paranaenses operaram, ainda, como uma espécie de 'leitura crítica' ou alternativa às coberturas midiáticas tradicionais, na medida em tais representações circulavam praticamente ao mesmo tempo em que o governo usava a estrutura da maquina pública para veicular as versões oficiais nos mais diversos meios do Estado (rádio, TV, impresso e digitais).

\section{Referências}

AMARAL, Adriana. Redes sociais, linguagens e disputas simbólicas. In: Revista ComCiência, nº131, versão online. Campinas, 2011. Disponível em: http://comciencia.scielo.br/scielo.php?script=sci_arttext\&pid=S151 9-76542011000700009\&lng=en\&nrm=iso

\section{BAKHTIN, Mikhail. A cultura popular na Idade Média e no} Renascimento: o contexto de François Rabelais. 5. ed. São Paulo: Hucitec/AnnaBlume, 2002.

BELTRÃO, Luiz. Folkcomunicação: a comunicação dos marginalizados. São Paulo: Cortez, 1980.

BLACKMORE, Susan. The Meme Machine. Oxford: Oxford University Press, 1999. 
BLACKMORE, Susan. The Power of Memes. Scientific American, New York, v. 283, p. 64-73, October, 2000.

DAWKINS, R. O Gene Egoísta. Tradução de Rejane Rubino. São Paulo: Companhia das Letras, 2007.

GADINI, S. Interesses cruzados: a produção da cultura no jornalismo brasileiro. São Paulo: Paulus, 2009.

GADINI, S.L. e CAMARGO, I. O. "Representações femininas a partir de grupos masculinos no carnaval brasileiro: uma perspectiva folkcomunicacional na maior festa popular do país". In: Razon y Palabra, Ago/Oct 2011, No 77. Disponível em http://www.razonypalabra.org.mx/N/N77-1/03_GadiniCamargo_M 77-1.pdf

RIBEIRO, Ana P. G. E SACRAMENTO, Igor (orgs). Mikhail Bakhtin: linguagem, cultura e mídia. São Carlos: Pedro e João Editores, 2010.

SOUZA, Caio Fabiano de. Memes: formações discursivas que ecoam no ciberespaço. In: Revista Vértices, v.15, nº 1, p.127-148. Rio de Janeiro, 2013. Disponível em:

http://www.essentiaeditora.iff.edu.br/index.php/vertices/article/vie w/1809-2667.20130011/2743 